\title{
The increased activity of TIMP-1 in the blood as a predictor of the recurrence of atrial fibrillation in the postoperative period
}

\author{
O.V. Goriachyi ${ }^{1,2}$, A.I. Gozhenko ${ }^{1}$, O.M. Levchenko ${ }^{1,2}$, O.V. Goriacha ${ }^{2}$ \\ ${ }^{1}$ Odessa Regional Clinical Hospital, ${ }^{2}$ Odessa National Medical University; \\ ${ }^{3}$ Ukrainian Scientific Research Institute of Transport Medicine; e-mail: avgoryachyi@gmail.com
}

The purpose of this study was to determine the relationship between tissue inhibitor of metalloproteinases-1 and atrial fibrillation recurrence after catheter ablation. Tissue inhibitor of metalloproteinases-1 (TIMP-1) is involved in extracellular matrix remodeling which is considered to be a marker of regulation of matrix metalloproteinase activity. An enzyme-linked immunosorbent assay prior to a radiofrequency catheter ablation (RFA) procedure was used for measuring the serum level of TIMP-1 in 210 patients: 80 patients without history of atrial fibrillation $(A F)$ and 130 patients with idiopathic $A F$ (paroxysmal $A F-30$, persistent $A F$ - 32, long-standing $A F-35$ and permanent $A F-33$ ). Their relationship with intraoperative efficacy and recurrence of $A F$ was evaluated throughout the entire observation period. The observation period was 22.2 \pm 7.9 months. TIMP-1 level was higher in the groups of patients with AF than in the control group: 131.51 $\pm 36.40,149.5 \pm 42.7,151.5 \pm 42.7$ and $155.9 \pm 44.7 \mathrm{ng} / \mathrm{ml}$ for paroxysmal, persistent, long-standing and permanent forms of AF. In the control group, TIMP-1 level was $103.6 \pm 14.7 \mathrm{ng} / \mathrm{ml}$. TIMP-1 level increased with the progression of AF. A multifactor analysis showed that TIMP-1 level, history of atrial fibrillation and left atrial volume were independent predictors of sinus rhythm recovery and recurrence of $A F$. An increase in TIMP-1 level in patients with AF has been shown. An increase in TIMP-1 levels was observed as AF progressed. TIMP-1 is prognostic criteria of arrhythmia recurrence after RFA.

Key words: TIMP-1; recurrence; fibrillation; ablation; matrix.

\section{INTRODUCTION}

Atrial fibrillation is the most common sustained arrhythmia in clinical practice. Recent prevalence estimates suggest that at least 33.5 million persons are affected by atrial fibrillation (AF) [1]. Its prevalence increases with age, from $0.1 \%$ in people younger than 55 years to more than $9 \%$ by 80 years of age [2]. Catheter ablation is the most promising treatment for AF. The multiple procedure success rate of pulmonary vein isolation for paroxysmal AF is approximately 70-80\% after long-term follow-up [3]. However, the success rates of pulmonary vein isolation for non-paroxysmal forms are ranging from $55-70 \%$ for persistent and 50-60\% for long standing AF. Recurrences are common after an initial procedure for non-paroxysmal forms of AF ablation and repeat ablation is often required to maintain freedom from AF [4]. Thus, new non-invasive preoperative predictors for assessment atrial structure remodeling are necessary to select the optimal ablation strategy for patients with AF.

Experimental and clinical researches have shown that, whatever the initial cause or trigger, there is a relationship between AF and alterations in atrial electrical properties [5]. The longer the duration of $\mathrm{AF}$, the more persistent it becomes because of atrial remodeling. Remodeling of cellular ultra-structures, such as myolysis occurring in the atrial myocardium, is known to develop progressively during AF [6]. An increase in the expression of the gap junctions (connexin 40) has been reported to induce changes in the biophysical

(C) O.V. Goriachyi, A.I. Gozhenko, O.M. Levchenko, O.V. Goriacha 
properties of the atrial tissue during AF [7, 8]. Enhanced disintegrin and metalloproteinase activity was also reported to be an important mechanism of AF [9] that could lead to atrium diameter expansion, atrial wall thinning and, thus, atrium structure reconstruction [10]. Endogenous proteolytic enzymes involved in extracellular matrix remodeling include the matrix metalloproteinases (MMPs) and the tissue inhibitors of metalloproteinases (TIMPs), consequently, the serum level of MMP-9, TIMP1 and their relationship are considered to be a marker of extracellular collagen degradation [11].

In particular, many reports have demonstrated that TIMP-1 may be implicated in the development of myocardial fibrosis. For example, the TIMP-1 level is an important index for myocardial fibrosis, [12] and also has a close relationship with other cardiovascular diseases [13]. The purpose of this study was to investigate the relationship between the serum TIMP-1 level and arrhythmia recurrence after catheter ablation in patients with AF at different stages of disease progression.

\section{METHODS}

This study included 210 consecutive patients with various forms of AF. The main group consisted of 130 patients with AF resistant to drug therapy. The control group consisted of 80 patients without heart rhythm disorders and practically healthy patients (Table 1 ). The mean age of patients in the main group was $53.5 \pm 7.6$ years, of them: $52(40 \%)$ women and $78(60 \%)$ men. The mean age of patients in the control group was $51.8 \pm 7.9$ years, of them: $41(51.3 \%)$ women and $39(48.8 \%)$ men. Both groups are comparable in age (U-test, $\mathrm{p}=0.17$ ) and gender (Fisher test, $\mathrm{P}=0.55)$. AF was diagnosed according to a manual (ESC Clinical Practice Guidelines 2016). Exclusion criteria were structural heart diseases; hematologic, renal, or hepatic disorders; inflammations; neoplastic diseases; recent ( $<3$ months) myocardial infarction or stroke; thyrotoxicosis-associated AF; or any acute infections. The study was approved by the Ethical Committee of the Odessa Regional Clinical Hospital, Odessa National Medical University. All patients signed an informed consent.

The day before the RFA, the serum TIMP-1 level was determined, and a transesophageal echocardiography was performed. The method for determining the serum TIMP-1 level is described in the literature [9]. In brief, blood samples were obtained by puncture of the peripheral vein and centrifuged at $3200 \mathrm{xg}$ for 10 minutes at a temperature of $4{ }^{\circ} \mathrm{C}$ within one hour after collection. The serum was separated and stored at a temperature of $-80^{\circ} \mathrm{C}$ until the patient-blinded personnel performed the analysis. The serum TIMP-1 level was determined using a standard commercial enzyme-linked immunosorbent assay in vivo according to the manufacturer's guidelines (Ray Biotech INC, Atlanta, Georgia, USA). The coefficient of variation within and between assays was $<10$ and $<12 \%$, respectively.

The anatomical study of the left atrium (LA) and pulmonary veins was carried out on a spiral computed tomography (computed tomography) scanner "HiSpeed computed tomography/i" manufactured by "General Electric" (USA), with a gantry rotation speed at spiral scanning of 1 rotation per second. The study was conducted against the background of the administration of non-ionic contrast agents using an automatic injector "SimtRac DH" manufactured by Siemens (Germany). The procedure was performed on an empty stomach, under conventional therapy. As a rule, the left cubital vein was punctured to perform a computed tomography scan with angiography of the LA and LV. A $20 \mathrm{G}$ venous catheter was inserted into the vein and an automatic injector was connected. The volume of the contrast agent and the rate of its injection were set up in the injector. The volume of the contrast agent depended on the patient's weight and height (usually 70-100 ml). Contrast agents "Iohexol (GE Healthcare AC, Ireland/Norway)" and "Iopromid (Bayer Pharma AG, Germany)" were used.

Data post-processing included the reconstruction of axial slices, the construction of 
two- and three-dimensional images. A softtissue filter was always used to reduce noise and increase contrast resolution. The results of the study were evaluated first by axial slices. Subsequently, reconstructed axial slices were used for a multiplanar reconstruction (multiplanar reconstruction). The construction of two- and three-dimensional reconstructions was performed on the GE workstation "Advantage Windows 2.0". The dimensions of the mouth of the pulmonary veins were measured in the axial plane and in the oblique plane of the multiplanar reconstruction. The three-dimensional reconstruction was performed in SSD mode, the anatomical structure of the left atrium and pulmonary veins was assessed (the number of veins flowing into the LA by their own mouth, the convergence of the pulmonary veins mouths, the common pulmonary veins collector).

All patients had a catheter AF ablation under general anesthesia. Patients were heparinized to maintain an activated clotting time for more than 300 s. A three-dimensional electroanatomical model was constructed using a NavX electroanatomical mapping system (St. Jude Medical, St. Paul, MN). The ablation procedure included following steps: 1) isolation of pulmonary veins, 2) linear ablation of the mitral isthmus, in the absence of an effect - ablation of the left atrial roof. In the absence of efficiency of the stages 1 and 2, linear ablations were additionally performed, which included a line along the posterior wall of the LV, a line along the cavotricuspid isthmus and isolation of the superior vena cava. The endpoint of the procedure was considered the termination of AF. In the absence of an effect, the sinus rhythm (sinus rhythm) was restored using electrical cardioversion.

According to the $2015 \mathrm{HRS} / \mathrm{EHRA} / \mathrm{ECAS}$ expert consensus statement on catheter and surgical ablation of AF, any atrial tachycardia (AT), atrial flutter (AFL) or an episode of AF lasting more than 30 seconds three months after ablation should be defined as a recurrence. All patients were monitored every month at the Polyclinic Department of the Odessa Regional
Clinical Hospital. If patients complained of heart palpitations, fatigue, or other symptoms related to arrhythmias, the patients underwent 24-hour ECG monitoring. Patients were also advised to visit the attending doctor at any time when they develop symptoms for a 12-lead ECG or 24hour ECG monitoring. Asymptomatic patients underwent 24-hour or situational ECG monitoring every 3 months after the procedure. The endpoint of the observation period was recording of an AT/AFL/AF recurrence with a duration of more than $30 \mathrm{~s}$.

Statistical data processing was carried out with the aid of the statistical package Statistica 6.1. Testing of the parameters for normality was carried out using the Kolmogorov-Smirnov and Shapiro-Wilk tests. Descriptive data for quantitative features with normal distribution were presented as mean and standard deviation $(\mathrm{M} \pm \sigma)$, those with non-normal distribution were presented in the form of median and interquartile interval $(\mathrm{Me})$. Correlation analysis was performed using the Spearman's R-test for quantitative values. The relationship between values was evaluated as significant at $R>\mid 0.7$ |, moderate at $\mathrm{R}$ from $|0.3|$ to $|0.7|$, weak at $\mathrm{R}<|0,3|$.

\section{Correlation analysis}

Calculations according to formula:

$|\mathrm{r}|=\left\{\exp \left[2 \mathrm{t} /(\mathrm{n}-1,5)^{0,5}-1\right\} /\left\{\exp \left[2 \mathrm{t} /(\mathrm{n}-1,5)^{0,5}+1\right\}\right.\right.$ give following threshold values of correlation coefficient modules for a sample of $n=130$ persons.

\section{RESULTS AND DISCUSSION}

In the postoperative period $(12.3 \pm 6.4$ months $)$, $35(26.9 \%)$ patients developed recurrent AT/AFL/ AF. The baseline characteristics of the patients in both groups are shown in Table 1. The data in the table showed no significant differences in age, gender, body mass index (body mass index), hypertension, left ventricle ejection fraction, or medication between the two groups. However, the group of patients with recurrent arrhythmias 
had a longer history of arrhythmias, greater LA diameter and a higher TIMP-1 level compared to the group without recurrence (Table 2).

We retrospectively analyzed data from patients in both groups. The level of the recovery of sinus rhythm at stages 1,2 and 3 in the two groups did not differ significantly. The only difference between the two groups was the linear ablation of the LA roof. At this stage, rhythm recovery was observed in 9 patients in group

Table 1. Baseline characteristics of the patients

\begin{tabular}{|c|c|c|c|c|c|c|}
\hline Parameters & $\begin{array}{l}\text { Paroxysmal } \\
\text { AF }(n=30)\end{array}$ & $\begin{array}{l}\text { Persistent AF } \\
\quad(\mathrm{n}=32)\end{array}$ & $\begin{array}{l}\text { Long-stand- } \\
\text { ing AF } \\
(\mathrm{n}=35)\end{array}$ & $\begin{array}{l}\text { Permanent } \\
\operatorname{AF}(n=33)\end{array}$ & $\begin{array}{l}\text { Control } \\
(\mathrm{n}=80)\end{array}$ & $\mathrm{P}$ \\
\hline & 30 & 32 & 35 & 33 & & \\
\hline Age (years) & $52.6 \pm 6.8$ & $53.4 \pm 7.2$ & $54.1 \pm 8.1$ & $53.9 \pm 8.2$ & $51.8 \pm 7.9$ & 0.41 \\
\hline Gender (male), n (\%) & $19(63.3)$ & $18(56.3)$ & $21(60)$ & $20(60.6)$ & $39(48.8)$ & 0.3 \\
\hline Gender (female), n (\%) & $11(36.7)$ & $14(43.8)$ & $14(40)$ & $13(39.4)$ & $41(51.3)$ & 0.28 \\
\hline Body mass index $\left(\mathrm{kg} / \mathrm{m}^{2}\right)$ & $25.9 \pm 4.9$ & $26.4 \pm 5.3$ & $27.1 \pm 4.4$ & $26.6 \pm 4.8$ & $26.7 \pm 4.5$ & 0.34 \\
\hline AF history (years) & $5.3 \pm 0.7$ & $6.1 \pm 0.6$ & $5.7 \pm 1.1$ & $6.4 \pm 1.3$ & - & 0.31 \\
\hline $\mathrm{AH}, \mathrm{n}(\%)$ & $19(63.3)$ & $20(62.5)$ & $23(65.7)$ & $21(63.6)$ & $11(13.8)$ & 0.2 \\
\hline IHD, n (\%) & $4(13.3)$ & $4(12.5)$ & $5(14.3)$ & $4(12.1)$ & - & 0.24 \\
\hline AH+IHD, n (\%) & $2(6.7)$ & $2(6.3)$ & $3(8.6)$ & $4(12.1)$ & - & 0.29 \\
\hline Idiopathic AF, n (\%) & $5(16.7)$ & $6(18.8)$ & $4(11.4)$ & $4(12.1)$ & - & 0.28 \\
\hline EHRA I, n (\%) & $5(16.7)$ & $5(15.6)$ & $10(28.6)$ & $15(45.5)$ & - & \\
\hline EHRA II, n (\%) & $19(63.3)$ & $18(56.3)$ & $4(11.4)$ & $10(30.3)$ & - & \\
\hline EHRA III, n (\%) & $6(20)$ & $9(28.1)$ & $21(60)$ & $8(24.2)$ & - & \\
\hline $\begin{array}{l}\text { Ventricular arrhythmias, } \\
\text { n (\%) }\end{array}$ & $11(36.7)$ & $11(34.4)$ & $12(34.3)$ & $11(33.3)$ & - & $* 0.38$ \\
\hline $\begin{array}{l}\text { Supraventricular arrhyth- } \\
\text { mias, } n(\%)\end{array}$ & $13(43.3)$ & $12(37.5)$ & $14(40)$ & $14(42.4)$ & $32(40)$ & $* 0.06$ \\
\hline NYHA I class, n (\%) & $18(60)$ & $6(18.8)$ & $6(17.1)$ & $6(18.2)$ & $27(33.8)$ & \\
\hline NYHA II class, n (\%) & $12(40)$ & $25(78.1)$ & $28(80)$ & $26(78.8)$ & - & \\
\hline absent & $0(0)$ & $1(3.1)$ & $1(2.9)$ & $1(3.0)$ & $53(66.3)$ & 0.45 \\
\hline TIMP-1, (ng/ml) & $131.51 \pm 36.40$ & $149.5 \pm 42.7$ & $151.5 \pm 42.7$ & $155.9 \pm 44.7$ & $103.6 \pm 14.7$ & 0.05 \\
\hline LA diameter, mm & $35.7 \pm 2.1$ & $41.4 \pm 3.2$ & $44.3 \pm 3.4$ & $47.5 \pm 4.4$ & $34.3 \pm 2.0$ & 0.05 \\
\hline $\begin{array}{l}\text { Right lower pulmonary } \\
\text { vein, mm }\end{array}$ & $15.6 \pm 0.7$ & $15.1 \pm 0.5$ & $15.1 \pm 0.8$ & $15.7 \pm 0.9$ & $14.8 \pm 0.7$ & 0.05 \\
\hline $\begin{array}{l}\text { Right upper pulmonary } \\
\text { vein, mm }\end{array}$ & $15.6 \pm 1.1$ & $15.9 \pm 0.9$ & $15.7 \pm 1.2$ & $16.0 \pm 1.3$ & $15.1 \pm 1.1$ & 0.05 \\
\hline $\begin{array}{l}\text { Left lower pulmonary } \\
\text { vein, mm }\end{array}$ & $14.5 \pm 1.2$ & $14.4 \pm 1.1$ & $14.1 \pm 1.3$ & $14.7 \pm 1.4$ & $14.3 \pm 1.2$ & 0.05 \\
\hline $\begin{array}{l}\text { Left upper pulmonary } \\
\text { vein, } \mathrm{mm}\end{array}$ & $16.0 \pm 1.1$ & $16.1 \pm 0.8$ & $15.8 \pm 1.2$ & $16.2 \pm 1.3$ & $15.3 \pm 1.1$ & 0.05 \\
\hline
\end{tabular}

$\mathrm{P}=$ Mann-Whitney test, $\mathrm{p}^{*}=$ Fisher criterion, $\mathrm{AF}=$ atrial fibrillation, $\mathrm{AH}=$ artery hypertension, IHD $=$ Ischemic heart disease, EHRA $=$ European heart rate association, NYHA $=$ New York Heart Association, $\mathrm{CHF}=$ chronic heart failure, TIMP-1 = tissue inhibitor of metalloproteinase -1 . 
1 and 7 patients in group $2(9.5 \%$ and $20 \%$, respectively, $\mathrm{P}=0.04$ ) (Table 3 ).

Correlation analysis of the TIMP-1 level, clinical and structural parameters of the left atrium revealed the following correlations: the strongest correlations were observed between the level of TIMP-1, the presence of arrhythmia and its severity and between the level of TIMP1 and right superior pulmonary vein diameter (Table 4).

If the effectiveness in the absence of recurrence after 2 years is estimated according to the Harrington scale using integers, we obtain a non-linear relationship graph.

If non-integers are used to quantify the severity of arrhythmias, we obtain a practically straight-line dependence of the effect of the operation on the severity of arrhythmia.

\section{Cluster analysis}

Using Cluster analysis, the preoperative level of TIMP-1was determined in patients with various effects of the operation (Table 5).

In the group of patients without relapse, TIMP-1 level was higher in the groups of patients with relapses of AF than in the group without relapses: $195.5 \pm 9.0,201,0 \pm 5,4$ and $129,2 \pm 3,4 \mathrm{ng} / \mathrm{ml}$ for the groups with relapse through 2 years and 7 days and in a group without relapse, respectively. In the group without effect, the MMP-9 level was $187,9 \pm 8,9 \mathrm{ng} / \mathrm{ml}$, which indicates the completion of structural

Table 2. Patients characteristics depending on the effectiveness of the ablation

\begin{tabular}{|c|c|c|c|}
\hline Parameters & $\begin{array}{l}\text { Without reccurence } \\
\qquad(\mathrm{n}=95)\end{array}$ & $\begin{array}{l}\text { With reccurence } \\
\qquad(\mathrm{n}=35)\end{array}$ & $\mathrm{P}$ \\
\hline Age (years) & $51.3 \pm 7.6$ & $54.6 \pm 7.9$ & 0.057 \\
\hline Gender (male), n (\%) & $50(52.6)$ & $18(51.4)$ & 0.83 \\
\hline Body mass index $\left(\mathrm{kg} / \mathrm{m}^{2}\right)$ & $26.1 \pm 4.9$ & $27.4 \pm 6.1$ & 0.33 \\
\hline AF history (months) & $43.2 \pm 15.9$ & $52.7 \pm 17.7$ & 0.03 \\
\hline Hypertension $\mathrm{n},(\%)$ & $12(12.6)$ & $4(11.4)$ & 0.82 \\
\hline Left atrial diameter $(\mathrm{mm})$ & $39.4 \pm 7.6$ & $44.8 \pm 9.2$ & 0.01 \\
\hline Left ventricle diameter $(\mathrm{mm})$ & $51.3 \pm 8.1$ & $53.4 \pm 7.3$ & 0.49 \\
\hline $\operatorname{LVEF}(\%)$ & $56.8 \pm 7.3$ & $57.5 \pm 9.2$ & 0.74 \\
\hline ACE inhibitor $n,(\%)$ & $19(20)$ & $4(11.4)$ & 0.36 \\
\hline Amiodarone $\mathrm{n},(\%)$ & $47(49.4)$ & $20(57.1)$ & 0.74 \\
\hline B-blockers n, (\%) & 87 (91.6) & $33(94.3)$ & 0.99 \\
\hline TIMP-1 (ng/ml) & $140,6 \pm 40,3$ & $152,7 \pm 44,9$ & 0.05 \\
\hline \multicolumn{4}{|l|}{ Catheter ablation results } \\
\hline Step 1: Pulmonary vein isolation $n,(\%)$ & $19(20)$ & $4(11.4)$ & 0.33 \\
\hline Step 2: linear ablation of left atrium $n,(\%)$ & $40(42.1)$ & $20(57.1)$ & 0.29 \\
\hline Mitral Isthmus ablation n, (\%) & $31(32.6)$ & $13(37.1)$ & 0.55 \\
\hline Left atrial roof $n,(\%)$ & $9(9.5)$ & $7(20)$ & 0.04 \\
\hline Step $1+2 \mathrm{n},(\%)$ & $59(62.1)$ & $241(68.6)$ & 0.61 \\
\hline Step 3: additional lines $n,(\%)$ & $34(35.8)$ & $11(31.4)$ & 0.33 \\
\hline Step $1+2+3 n,(\%)$ & $76(80)$ & $26(74.3)$ & 0.08 \\
\hline Electrical cardioversion $n,(\%)$ & $15(15.8)$ & $9(25)$ & 0.15 \\
\hline
\end{tabular}

$\mathrm{P}=$ Mann-Whitney test, AF $=$ atrial fibrillation, $\mathrm{LVEF}=$ left ventricle ejection fraction, $\mathrm{ACE}=$ angiotensin-converting-enzyme, TIMP-1 = tissue inhibitor of metalloproteinase-1. 
Table 3. Four-fold matrix of the relationship between the form of atrial fibrillation and operation efficacy

\begin{tabular}{|c|c|c|c|c|c|c|c|}
\hline \multirow[b]{2}{*}{ Types of AF } & & \multicolumn{4}{|c|}{ Effect after procedure } & \multirow[b]{2}{*}{ Total } & \multirow[b]{2}{*}{$\begin{array}{l}\left(\Sigma \mathrm{n}^{2} /\right. \\
\mathrm{Nx}) / \mathrm{N}\end{array}$} \\
\hline & & $\begin{array}{l}\text { Without } \\
\text { reccurence }\end{array}$ & $\begin{array}{l}\text { Reccurence } \\
\text { after } 2 \text { years }\end{array}$ & $\begin{array}{l}\text { Reccurence } \\
\text { after } 7 \text { days }\end{array}$ & $\begin{array}{l}\text { Without } \\
\text { effect }\end{array}$ & & \\
\hline \multirow[t]{2}{*}{ Paroxysmal AF } & $\mathrm{n}$ & 25 & 0 & 2 & 1 & 28 & \\
\hline & $\mathrm{n}^{2} / \mathrm{Nx}$ & 20.346 & 0 & 0.154 & 0.038 & 20.538 & 0.790 \\
\hline \multirow[t]{2}{*}{ Persistent AF } & $\mathrm{n}$ & 22 & 2 & 3 & 4 & 31 & \\
\hline & $\mathrm{n}^{2} / \mathrm{Nx}$ & 15.613 & 0.516 & 0.290 & 0.516 & 16.548 & 0.534 \\
\hline \multirow[t]{2}{*}{ Long-standing AF } & $\mathrm{n}$ & 25 & 4 & 4 & 3 & 36 & \\
\hline & $\mathrm{n}^{2} / \mathrm{Nx}$ & 17.361 & 0.444 & 0.444 & 0.250 & 18.499 & 0.514 \\
\hline \multirow[t]{2}{*}{ Permanent AF } & $\mathrm{n}$ & 23 & 4 & 5 & 3 & 35 & \\
\hline & $\mathrm{n}^{2} / \mathrm{Nx}$ & 15.114 & 0.457 & 0.714 & 0.257 & 16.543 & 0.473 \\
\hline Total & $\mathrm{Ny}$ & 95 & 10 & 14 & 11 & 130 & 2.311 \\
\hline
\end{tabular}

$\mathrm{AF}-$ atrial fibrillation,

$\xi^{2}=\left[\left(\Sigma \mathrm{n}^{2} / \mathrm{Nx}\right) / \mathrm{N}\right]-1=1,311$

$\varphi^{2}=\xi^{2}-(\mathrm{x}-1)(\mathrm{y}-1) / \mathrm{N}=1,311-(4-1)(4-1) / 130=1,241$

$\mathrm{R}=\left\{\varphi^{2} /\left(1+\varphi^{2}\right)[\mathrm{xy} /(\mathrm{x}-1)(\mathrm{y}-1)]^{0,5}\right\}^{0,5}=\left[1.241 / 2.241 \cdot(16 / 9)^{0,5}\right]^{0,5}=0,860$

$\mu_{\mathrm{R}}=\left(1-\mathrm{R}^{2}\right) /(\mathrm{N}-2)^{0,5}=0.023$

$\mathrm{R}=0.860 \pm 0.023$.

myocardial remodeling. In the control group, TIMP-1 level was $170,0 \pm 2,0 \mathrm{ng} / \mathrm{ml}$. TIMP-1

Table 4. Matrix of correlation relationships between enzymes/cytokines, clinical indices and left atrial structural parameters

\begin{tabular}{l|c|}
\hline \multicolumn{1}{|c|}{ Parameters } & $\begin{array}{r}\text { Proteinase inhibitor, } \\
\text { TIMP-1 }\end{array}$ \\
\hline Clinical indices: & \\
HD & 0.50 \\
IHD & 0.41 \\
Arhythm-1 & 0.73 \\
EHRA & 0.70 \\
NYHA & 0.12 \\
Sex & -0.01 \\
Age & 0.13 \\
Left atrial parameters: & \\
LAVZ & 0.59 \\
LAV & 0.76 \\
RIPV & 0.83 \\
RSPV & 0.96 \\
LIPV & 0.93 \\
LSPV & 0.93 \\
\hline
\end{tabular}

level increases with the progression of AF until complete structural myocardial remodeling.

It should be noted that the clinical features of the patients played an important role on the consequences of the operation (Table 6). The main contribution to the recurrence of atrial fibrillation made hypertonic disease and heaviness of the arrhythmia.

\section{CONCLUSION}

In the present study, we have prospectively studied the TIMP-1 level as predictors of the recurrence of arrhythmia after a procedure of RFA of AF. We found that TIMP-1 levels in patients with AF were significantly higher those in the healthy control population, indicating that TIMP-1 may play a role in the occurrence and maintenance of AF.

For the first time, a close relationship between TIMP-1 and AF [14] was demonstrated. It has been shown that increased expression of TIMP-1 may contribute to the structural remodeling of atriums and to atrial dilatation during AF. TIMP-1 also participates in atrial 
Table 5. Peculiarities of the MMP-9 level of patients with various consequences of the operation

\begin{tabular}{|c|c|c|c|c|c|c|}
\hline Inhibitor & Cluster & NR & R2y & R7d & NE & Norm \\
\hline TIMP-1 & $\mu \mathrm{g} / \mathrm{L}$ & $129.2 \pm 3.4$ & $195.5 \pm 9,0$ & $201.0 \pm 5.4$ & $188.4 \pm 8.3$ & $170.0 \pm 2.0$ \\
\hline
\end{tabular}

TIMP-1 = tissue inhibitor of metalloproteinase $-1, \mathrm{NR}=$ no relapse, $\mathrm{R} 2 \mathrm{y}=$ relapse in 2 days, $\mathrm{R} 7 \mathrm{~d}=$ relapse in 7 days, $\mathrm{NE}=$ no effect.

remodeling after catheter ablation. In addition, a significant increase in TIMP-1 regulation is associated with a large decrease in the size of the left atrium [15]. Patients who developed recurrence had a higher serum TIMP-1 level, indicating a more serious atrial remodeling and form of AF. These assumptions were confirmed by a long history of AF and large sizes of the LA in this group. To date, the efficacy of RFA in patients with persistent, long-standing and permanent forms of AF remains unsatisfactory. Despite the adoption of new techniques, recent studies have shown that up to $40 \%$ of patients had a recurrence of tachycardia after the primary procedure [16]. What patient characteristics can be used to evaluate their prognosis remains unclear. Various candidates were reported to predict the recurrence of AF after catheter ablation, including age, gender, body mass index, ECG, echocardiographic data, observations made using cardiovascular magnetic resonance imaging (magnetic resonance imaging) and some serum or plasma factors [17]. Some of these studies contradict one another, while the most accurate predictors of recurrences after ablation of $\mathrm{AF}$ remain uncertain. AF progresses with worsening fibrosis and inflammation. Various inflammatory factor cause focal myocardial necrosis, modulate the functionality of the ion channel, and then initiate structural and electrical atrial remodeling. TIMP-1 is one of the markers of fibrosis and inflammation, which is associated with atrial remodeling in patients with AF. Elevated levels of TIMP-1 are associated with the occurrence and maintenance of AF [18]. In this article, we investigated the factors that may have prognostic significance for the results of catheter ablation of AF in the early and late postoperative period. We observed that traditionally reported factors, such as a history of AF and left atrium diameter, were also significantly associated with AF recurrence. In addition, the serum TIMP-1 level was found to be an independent predictor of recurrence. Thus, to eliminate this bias, the presence of AF without structural heart disease was confirmed in all patients registered in our study. Our data showed that serum TIMP-1 level was effective in predicting the recurrence of AF in this cohort.

The patients included in this study were

Table 6. Peculiarities of the clinical status of patients with different consequences of the operation

\begin{tabular}{l|c|c|c|c|c|c|}
\hline $\begin{array}{c}\text { Clusters } \\
\text { of consequences } \\
(\mathrm{n})\end{array}$ & $\begin{array}{c}\text { Hypertonic } \\
\text { Disease } \\
(\mathrm{No}=0 ; \\
\text { Yes=1) }\end{array}$ & $\begin{array}{c}\text { Ischemic } \\
\text { Heart Dis- } \\
\text { ease }(\mathrm{No}=0 ; \\
\text { Yes=1) }\end{array}$ & $\begin{array}{c}\text { NYHA }(0 ; \\
1 ; 2)\end{array}$ & $\begin{array}{c}\text { EHRA }(1 ; \\
2 ; 3)\end{array}$ & $\begin{array}{c}\text { Arhythmia-1 } \\
\text { No=0; Supra- } \\
\text { ventricular=1; } \\
\text { Ventricular=2) }\end{array}$ & $\begin{array}{c}\text { Arhythmia-2 } \\
\text { Fibrillation } \\
\text { Heaviness, } \\
\text { points }\end{array}$ \\
\hline $\begin{array}{l}\text { No Relapse (95) } \\
\text { Relapse after 2 }\end{array}$ & $1.72 \pm 0.05$ & $0.08 \pm 0.03$ & $1.31 \pm 0.08$ & $1.76 \pm 0.07$ & $0.83 \pm 0.07$ & $2.15 \pm 0.07$ \\
$\begin{array}{l}\text { years (10) } \\
\text { Relapse after7 days }\end{array}$ & $0.50 \pm 0.17$ & $1.50 \pm 0.27$ & $2.80 \pm 0.20$ & $1.90 \pm 0.10$ & $2.57 \pm 0.08$ \\
(14) & $0.86 \pm 0.10$ & $0.57 \pm 0.14$ & $1.57 \pm 0.23$ & $2.93 \pm 0.07$ & $1.93 \pm 0.07$ & $2.35 \pm 0.16$ \\
No Effect (11) & $0.91 \pm 0.09$ & $0.36 \pm 0.15$ & $1.16 \pm 0.29$ & $2.41 \pm 0.32$ & $1.41 \pm 0.28$ & $2.37 \pm 0.15$ \\
\hline
\end{tabular}

EHRA $=$ European heart rate association, NYHA $=$ New York Heart Association 
a special group of AF. The TIMP-1 level correlates with the intraoperative efficacy of rhythm recovery and relapse in the early and late postoperative period and increases as AF progresses. Patients with constant AF had more extensive fibrosis than patients with persistent AF [19]. Constant AF usually coexists with structural heart disease, which can aggravate fibrosis and inflammation. In recent recommendations, catheter ablation is not recommended for patients with constant AF. This study evaluated only patients with idiopathic AF without apparent structural concomitant pathology which could limit its generalizability. Serum TIMP-1 levels were higher in patients with recurrence and were identified as an independent predictor of arrhythmia recurrence after catheter ablation. In conclusion, we explained that the expression of TIMP-1 increases with the progression of AF and may contribute to structural atrial remodeling and increase the risk of relapse in the postoperative period. This requires the use of more complex integrated approach for the treatment.

The authors of this study confirm that the research and publication of the results were not associated with any conflicts regarding commercial or financial relations, relations with organizations and/or individuals who may have been related to the study, and interrelations of coauthors of the article.

\section{А.В. Горячий ${ }^{1,2}$, А.И. Гоженко ${ }^{3}$, Е.М. Левченко ${ }^{1,2}$, А.В. Горячая ${ }^{2}$ \\ ПОВЫШЕНИЕ АКТИВНОСТИ ТКАНЕ- ВОГО ИНГИБИТОРА МЕТАЛЛОПРОТЕИ- НАЗЫ -1 В КРОВИ КАК ПРЕДИКТОРА РЕ- ЦИДИВА ФИБРИЛЛЯЦИИ ПРЕДСЕРДИЙ В ПОСЛЕОПЕРАЦИОННОМ ПЕРИОДЕ}

Определяли влияние содержания тканевого ингибитора металлопротеиназы-1 (ТИМП-1) на рецидивирование фибрилляции предсердий (ФП) после процедуры катетерной радиочастотной абляции (КРА). ТИМП-1 участвует в ремоделировании внеклеточного матрикса, который считается маркером регуляции активности матриксных метал- лопротеиназ. С помощью иммуноферментного анализа до процедуры КРА измеряли сывороточное содержание ТИМП-1 у 210 пациентов: 80 пациентов без анамнеза и 130 с идиопатической формой ФП (пароксизмальная-30, персистирующая-32, длительно-персистирующая-35 и хроническая-33). Оценивали их связь с интраоперационной эффективностью и рецидивом ФП в течение всего периода наблюдения, который составил 22,2 \pm 7,9 мес. Содержание ТИМП-1 было выше в контрольной группе (103,6 $\pm 14,7$ нг / мл), у пациентов с ФП-131,51 $\pm 36,40,149,5 \pm 42,7,151,5 \pm 42,7$ и $155,9 \pm 44,7$ нг / мл для пароксизмальной, персистирующей, длительноперсистирующей и постоянной форм соответственно. С прогрессирование ФП этот показатель увеличивался. Многофакторный анализ показал, что содержание ТИМП-1, анамнез ФП и объем левого предсердия были независимыми предикторами восстановления синусового ритма и рецидива после процедуры КРА. ТИМП-1 является прогностическим критерием рецидива аритмии после КРА.

Ключевые слова: ТИМП-1; рецидив; фибрилляция; абляция; матрица.

${ }^{1}$ Одесская областная клиническая больнича;

${ }^{2}$ Одесский национальный медицинский университет;

${ }^{3}$ Украинский научно-исследовательский институт транспортной медицины

О.В. Горячий ${ }^{1,2}$, А.І. Гоженко ${ }^{3}$, О.М. Левченко ${ }^{1,2}$, O.В. Горяча ${ }^{2}$

\section{ПІДВИЩЕННЯ АКТИВНОСТІ ТКАНИН- НОГО ІНГІБІТОРА МЕТАЛОПРОТЕЇНА- ЗИ-1 ЯК ПРЕДИКТОРА РЕЦИДИВУ ФІБРИ- ЛЯЦІЇ ПЕРЕДСЕРДЬ У ПІСЛЯОПЕРАЦІЙ- НОМУ ПЕРІОДІ}

Визначали вплив вмісту тканинного інгібітора металопротеінази-1 (ТІМП-1) на рецидивування фібриляції передсердь (ФП) після процедури катетерної радіочастотної абляції (КРА). ТІМП-1 бере участь у ремоделюванні позаклітинного матриксу, який вважається маркером регуляції активності матриксних металопротеїназ. За допомогою імуноферментного аналізу до процедури КРА вимірювали сироватковий вміст ТІМП-1 у 210 пацієнтів: 80 пацієнтів без анамнезу ФП і 130 з ідіопатичною формою ФП (пароксизмальна-30, персистуюча-32, тривало-персистуюча-35 і хронічна-33). Оцінювали їх зв'язок з інтраопераційною ефективністю і рецидивом ФП протягом усього періоду спостереження, який становив $22,2 \pm 7,9$ міс. Вміст ТІМП1 був вище в контрольній групі $(103,6 \pm 14,7$ нг/мл), у пацієнтів з ФП-131,51 $\pm 36,40,149,5 \pm 42,7,151,5 \pm 42,7$ i $155,9 \pm 44,7$ нг/мл для пароксизмальної, персистуючої, тривалої і постійної форм відповідно. 3 прогресування ФП цей показник збільшувався. Багатофакторний аналіз показав, що вміст ТІМП-1, анамнез ФП і об'єм лівого передсердя були незалежними предикторами відновлення 
синусового ритму і рецидиву після процедури КРА. ТІМП-1 $\epsilon$ прогностичним критерієм рецидиву аритмії після КРА. Ключові слова: ТІМП-1; рецидив; фібриляція; абляція; матриця.

${ }^{1}$ Одеська обласна клінічна лікарня;

${ }^{2}$ Одеський наиіональний медичний університет;

${ }^{3}$ Украйнський науково-дослідний інститут транспортноїмедицини, Oдеса; e-mail: avgoryachyi@gmail.com

\section{REFERENCES}

1. Chugh SS, Havmoeller R, Narayanan K, Singh D, Rienstra M, Benjamin EJ, Gillum RF, Kim YH, McAnulty JH Jr, Zheng ZJ, Forouzanfar MH, Naghavi M, Mensah GA, Ezzati M, Murray CJ. Worldwide epidemiology of atrial fibrillation: a Global Burden of Disease 2010 Study. Circ 2014; 129:837-47.

2. Staerk L, Sherer J, Ko D, Benjamin E, Helm R. Atrial Fibrillation epidemiology. Pathophysiol and Clin Outcomes Circ. 2017; 120:1501-17.

3. Pappone C, Vicedomini G, Augello G, Manguso F, Saviano M, Baldi M, et al. Radiofrequency catheter ablation and antiarrhythmic drug therapy: a prospective, randomized, 4-year follow-up trial: the APAF study. Circ Arrhythm Electrophysiol. 2011; 4(6):808-14.

4. Calkins H, Kuck KH, Cappato R, Brugada J, Camm AJ, Chen SA, et al. 2012 HRS/EHRA/ECAS Expert consensus statement on catheter and surgical Ablation of atrial fibrillation: recommendations for patient selection, procedural techniques, patient management and followup, definitions, endpoints, and research trial design. Europace. 2012; 14(4): 528-606.

5. Kabra R, Heist EK, Barrett CD, et al. Incidence and electrophysiologic properties of dissociated pulmonary vein activity following pulmonary vein isolation during catheter ablation of atrial fibrillation. J Cardiovasc Electrophysiol. 2010; 21:1338-43.

6. Noureldin M., Chen H., Bai D. Functional Characterization of novel atrial fibrillation-linked GJA5 (Cx40) Mutants. Int J Mol Sci. 2018; 19:977

7. Paramdeep S Dhillon, Rasheda A Chowdhury, Pravina M Patel et al. Relationship Between Connexin Expression and Gap-Junction resistivity in human atrial myocardium. Circ Arrhythm and Electrophysiol. 2014;7:321-29.

8. Norihiro Ueda, Mitsuru Yamamoto, Haruo Honjo, et al. The role of gap junctions in stretch-induced atrial fibril- lation. Cardiovasc Res 2014; 104; 364-70.

9. Takahashi N, Kume O, Wakisaka O, et al. Novel strategy to prevent atrial fibrosis and fibrillation. Circ J 2012; 76: 2318-26.

10. Kostin S, Klein G, Szalay Z, et al. Structural correlate of atrial fibrillation in human patients. Cardiovasc Res 2002; 54: 361-79.

11. Veidal SS, Nielsen MJ, Leeming DJ, et al. Phosphodiesterase inhibition mediates matrix metalloproteinase activity and the level of collagen degradation fragments in a liver fibrosis ex vivo rat model. BMC Res Notes 2012; 5: 686.

12. Fan D, Takawale A, Lee J, et al. Cardiac fibroblasts, fibrosis and extracellular matrix remodeling in heart disease. Fibrogenesis Tissue Repair. 2012; 5: 15.

13. Renko J, Kalela A, Jaakkola O, et al. Serum matrix metalloproteinase- 9 is elevated in men with a history of myocardial infarction. Scand J Clin Lab Invest. 2004; 64:255-61.

14. Nakano Y, Niida S, Dote K, Takenaka S, Hirao H, Miura F, et al. Matrix metalloproteinase- 9 contributes to human atrial remodeling during atrial fibrillation. J Am Coll Cardiol. 2004;43(5):818-25.

15. Richter B, Gwechenberger M, Socas A, Zorn G, Albinni $\mathrm{S}$, Marx M, et al. Time course of markers of tissue repair after ablation of atrial fibrillation and their relation to left atrial structural changes and clinical ablation outcome. Int J Cardiol. 2011;152(2):231-6.

16. Mont L, Bisbal F, Hernandez-Madrid A, Perez-Castellano N, Vinolas X, Arenal A, et al. Catheter ablation vs. antiarrhythmic drug treatment of persistent atrial fibrillation: a multicentre, randomized, controlled trial (SARA study). Eur Heart J. 2014;35(8):501-7.

17. Wynn GJ, Das M, Bonnett LJ, Panikker S, Wong T, Gupta D. Efficacy of catheter ablation for persistent atrial fibrillation: a systematic review and meta-analysis of evidence from randomized and nonrandomized controlled trials. Circ Arrhythm Electrophysiol. 2014;7(5):841-52.

18. Combes S, Jacob S, Combes N, Karam N, Chaumeil A, Guy-Moyat B, et al. Predicting favourable outcomes in the setting of radiofrequency catheter ablation of longstanding persistent atrial fibrillation: a pilot study assessing the value of left atrial appendage peak flow velocity. Arch Cardiovasc Dis. 2013;106(1):36-43.

19. Lewkowicz J, Knapp M, Tankiewicz-Kwedlo A, Sawicki $\mathrm{R}$, Kaminska M, Waszkiewicz E, et al. MMP-9 in atrial remodeling in patients with atrial fibrillation. Ann Cardiol Angeiol (Paris). 2015. 